\title{
Physical simulation of integrated protective structures
}

\author{
Serhii Nehrii $^{1}{ }^{*}$, Tetiana Nehrii $^{1}$, and Hanna Piskurska ${ }^{2}$ \\ ${ }^{1}$ Donetsk National Technical University, Department of Mineral Deposits, 2 Shybankova Sq., \\ 85300 Pokrovsk, Ukraine \\ ${ }^{2}$ Donetsk National Technical University, Department of Language Training, 2 Shybankova Sq., \\ 85300 Pokrovsk, Ukraine
}

\begin{abstract}
An effective way of protecting development workings by integrated rock wall structures is considered. The necessity of improving this method and its experimental verification is substantiated. Integrated rock wall structures are experimentally tested under laboratory conditions. On the basis of the results of physical modeling, parameters of integrated structures have been specified in terms of impact factors; their yield strength is also specified. The condition for ensuring the stability of the integrated protective structure, which allows calculating appropriate rock wall width, is determined.
\end{abstract}

\section{Introduction}

Under conditions of coal seam mining by underground method, the question of maintaining the stability of mining operations is becoming rather relevant, since it effects mineral extraction schedule and mine safety $[1-4]$. A lot of studies abroad and in Ukraine are devoted to this issue. In particular, theoretical and practical results of research on the stability of rock contour of workings are given in terms of impact factors. In most cases, they are based on mine field observations [5-10, 17], physical modeling [10-14], numerical methods $[5,10,12,15,18,19]$, etc.

New ways of protecting workings are being designed and existing ones are being improved by means of well-known research methods. For example, methods of physical modeling and numerical methods are widely used to study stress-strain state of an array around mine workings and to substantiate technological parameters $[5,10-12,16,19,20]$. Mine observations are mostly used to obtain raw data for designing and testing the technologies under study $[6-8,17,20]$.

Currently, more and more studies are being devoted to the development of effective resource-saving means of protecting development workings, which are built behind the longwall face on the line between the working and the mind-out space. Most widespread protective methods do not produce the desired results because they have a limited scope of use, and their yielding is high. Besides, they are rather costly to implement. For example, workings protection by means of ordinary rock is not always effective because it has a high degree of shrinkage. On the other hand, these technologies have the following advantages:

\footnotetext{
* Corresponding author: serhii.nehrii@,donntu.edu.ua
} 
firstly, rock is left in the mine; secondly, natural materials are used for the construction. This allows reducing the cost of protective means and transportation costs. Along with this, miners' wages increases because of considerable labour intensity. Therefore, in order to ensure the effectiveness of the protective means by using ordinary rocks, it is necessary to eliminate these shortcomings. This is possible when the necessary amount of rock is reduced in structures due to the use of restraining elements. Therefore, the issue of improving the traditional means of protecting workings and developing new ones is relevant and can be solved by means of proven methods and techniques.

\section{Reference to scientific and practical results}

The traditional way of protection by means of ordinary rock is constructing a rock wall along the working on the border with the mined-out space. In this case mining rock or special deading rock is used. But this is the least efficient technology, because its implementation requires a large amount of rock and significant labor costs. In addition, it has the yield strength of 40 to $65 \%$, which negatively affects the state of the working.

Currently, the Department of Mineral Deposits in Donetsk National Technical University of Ministry of Education and Science of Ukraine is working on developing and improving the means of protection. In most cases, these are effective and low-cost technologies based on the use of ordinary rocks and restraining elements. These include the integrated protective structures, which means that two bag walls filled with fine-friction rock are laid out behind the longwall face on the line between the working and the mind-out space, and ordinary rock of any fraction is placed in the cavity between them (Fig. 1).

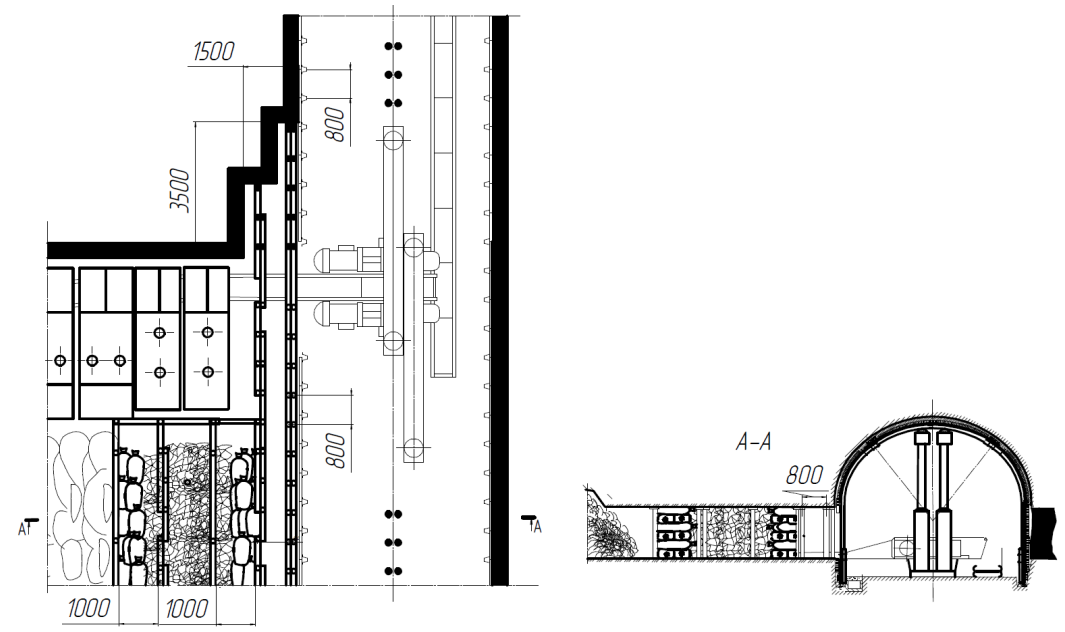

Fig. 1. Technological scheme of lining the final part of the longwall face and erecting the integrated protective rock structure [22].

According to the results of previous laboratory and analytical studies the parameters of this technology have been determined [21, 22]. But a small number of parameters which varied in a limited range have been considered in laboratory models. Besides, theoretical calculations also need practical confirmation. That is, it would be advisable to carry out a research phase to improve this technology and prove the adequacy of theoretical results in practice.

Thus, the purpose of the research is to justify the parameters of an integrated protective rock structure on the basis of the results of physical modeling. 


\section{Determining the parameters of integrated protective structures}

In order to achieve this aim, the research phase was based on laboratory testing of rock constructions, which were models of the suggested protective means and had different linear parameters. That is, if we take as a ground the fact that the minimum required width of the rock wall should be equal to 8 seam height, but not less than $5 \mathrm{~m}$ [23], the minimum required conditions for maintaining the operational state of workings will be provided. Therefore, additional measures to improve the protective means will not be required. However, if it is necessary to reduce the structure yielding strength or the rock volume, provided that the state of the working is maintained or improved, the use of such restraining surfaces as bag walls is recommended.

Previously, it was found out that walls should contain two bags in a row laid perpendicular to each other along the height of the protective structure [21], but by changing the rock width between these walls, it is possible to change their bearing capacity and yielding strength, as well as affect the stability of the working. The rock wall width can be calculated by the equation [22]:

$$
x=\frac{\operatorname{tg}^{2}\left(45^{\circ}-\frac{\phi}{2}\right) h}{2 f} \ln \frac{\sigma_{y}}{P_{b}},
$$

where $h$ is height of the structure, $\mathrm{m} ; \sigma_{y}$ is stress over the protective structure caused by the weight of the rocks held by the structure, MPa; $f$ is coefficient of rock friction within the structure against the material of its shell; $\varphi$ is angle of internal friction of rocks, degrees; $P_{b}$ is stress occurring when ordinary rocks contact the bag wall, MPa.

The integrated structure involves erection of walls made of bags and rock packs, but from the equation (1) it follows that at $\sigma_{y}=P_{b}$ the rock pack is not required, and this construction will be similar to the method of protecting by rock walls [21, 24]. In the case when $\sigma_{y}>P_{b}$, it will be insufficient to make use of rock pack only, so it is necessary to fill space between them with ordinary rocks, i.e. to construct a rock wall. The width of the rock pack may be from several tens of centimeters to several meters, depending on the impact factors.

To determine the reaction of the bag wall $P_{b}$, we will present a calculation scheme for the redistribution of forces along the width of the protective structure (Fig. 2). It is evident that under the action of forces, there occur extrusion forces caused by rock weight forces $\sigma_{y}$ in the rock pack toward the walls, while $P_{b}$ forces withstand them. In turn, $P_{b}$ forces are caused by the friction force of the bags between themselves against the rocks of the hanging layer and the ground because of the force action $\sigma_{y}$ and the weight of the bags. Thus, $\sigma_{y}$ affects both rock structure destroying and its holding.

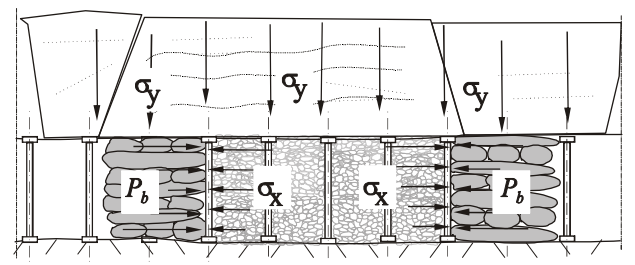

Fig. 2. The scheme of force distribution along the width of the integrated protective structure.

The $P_{b}$ can be determined experimentally by studying the separated rock bag walls using structural models (Fig. 3). For this purpose, cotton bags filled with fine fraction rock 
were made in the scale of modeling M1:25, according to the similarity conditions [25]. The length of the bags was $45 \mathrm{~mm}$ and the diameter was $12.5 \mathrm{~mm}$. In the rows of the walls the bags were perpendicular to each other along the required height. The width of the rock walls was $45 \mathrm{~mm}$, which equaled $1.13 \mathrm{~m}$ in full size. Their length was $120 \mathrm{~mm}(3.0 \mathrm{~m}$ in full size), and the height depended on the number of rows of bags in the wall. It was 40 $(1.0 \mathrm{~m}), 65(1.63 \mathrm{~m})$ and $90 \mathrm{~mm}(2.25 \mathrm{~m})$ for 3,5 and 7 rows respectively.

Several models of different height were made. They were tested on a hydraulic press in turns. For this purpose, they were squeezed with a pressing force of $0.5 \mathrm{kN}$, then the bags were pushed horizontally in different points of the wall with the help of a metal rod and a dynamometer (Fig. 3).

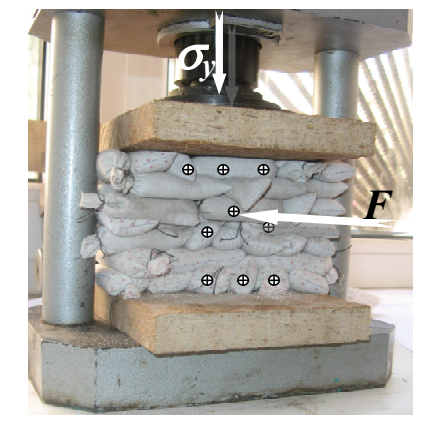

Fig. 3. Representation of the rock wall made of bags.

In each wall, when pushing the bag, the dynamometer readings were recorded at the moment of shift in a specified location. Then the construction returned to its starting position and measured again. Since the pushing force $F$ is equal to the maximum reaction of the wall $P_{b}$, it is possible to determine the relative index $\psi$ if we know $\sigma_{y}$ and $F$. The index shows the portion of wall reaction in the total loading value $\sigma_{y}$, that is

$$
\psi=\frac{P_{b}}{\sigma_{y}} .
$$

Subsequently, with this indicator the equation (1) will be as follows:

$$
x=-\frac{\operatorname{tg}^{2}\left(45^{\circ}-\frac{\phi}{2}\right) h}{2 f} \ln \psi,
$$

which implies the condition for the stability of the construction:

$$
\frac{x}{h} \geq-\frac{\operatorname{tg}^{2}\left(45^{\circ}-\frac{\phi}{2}\right)}{2 f} \ln \psi .
$$

Having obtained the results of numerical measurements, we were able to establish the dependence of the indicator $\psi$ on the height of the structure (Fig. 4), which implies that the middle row of the construction has the minimum value, and the lowest one has the maximum value. But if we compare graphs showing different amounts of bags along the height, the values of the indicator $\psi$ in the middle rows of different models are almost identical and differ by no more than $5 \%$. For the upper and lower rows the pattern is similar and the deviations do not exceed 9 and $6 \%$, respectively. 


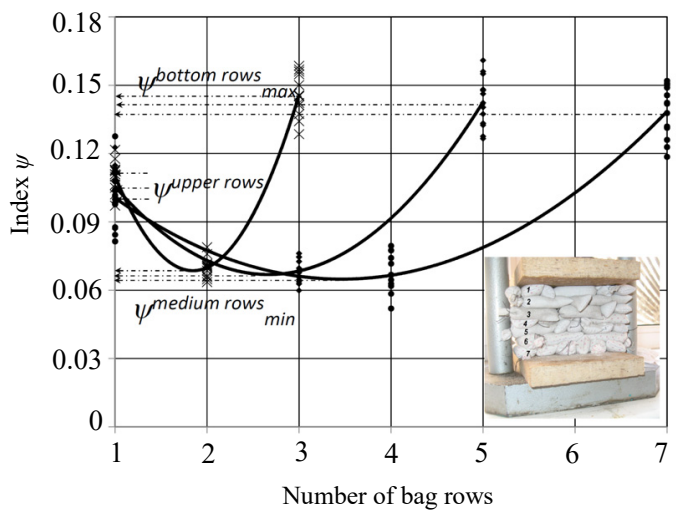

Fig. 4. Graphs showing dependence of the relative index $\psi$ on the rock wall height expressed by number of bag rows.

To calculate $x$ by the equation (3) in order to ensure the stability of the structure, it is necessary to assume the minimum value of the index $\psi_{\min }=0.065$, which is obtained for the middle row, regardless of the number of bags in the row. Following from the equation (3) and taking into account this index, the condition (4) will take the following form:

$$
\frac{x}{h} \geq \frac{\operatorname{tg}^{2}\left(45^{\circ}-\frac{\phi}{2}\right)}{0.73 f} .
$$

To confirm experimentally the obtained results, the following stage of structural modeling was carried out on the scale M 1:25. 19 models were made; they differed from each other in terms of width of the rock pack between the bag walls (Fig. 5). The bags were made of cotton fabric and filled with quartz sand. For the narrowest model, the rock pack width was calculated according to the equation (3) and was $1.22 h$, so the width of this model was $3.5 h$, including the rock pack $1.3 h$ wide. Additionally, several models containing rock walls without bags were made (Fig. 6), as well as models made of rock walls $1.1 h$ and $2.2 h$ wide (where $h$ is the initial height of the model) (Fig. 7).

Rock with the same fraction composition was placed in the rock packs. The constructions presupposed installing wooden racks, laying bags and burying the rock (Fig. 8).

$a$

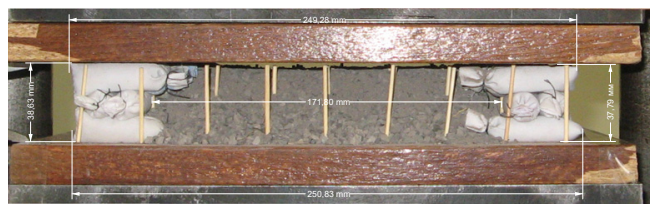

$b$

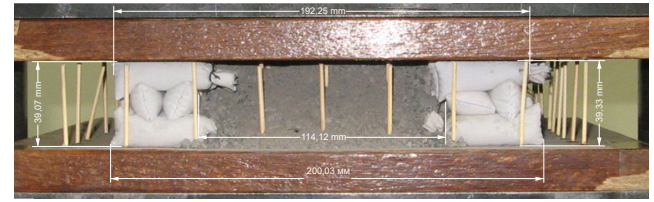

C

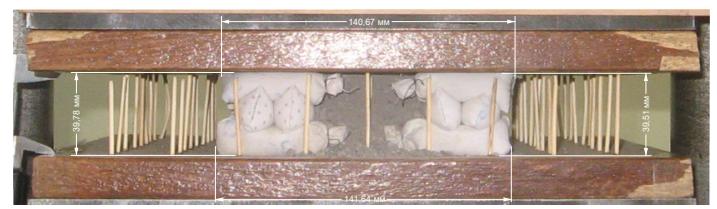

Fig. 5. Representation of the models of integrated structures made of bag walls and rock pack $(a, b$, $c$ - rock pack width, respectively, $4.3 h, 2.8 h$ and $1.3 h$ ). 


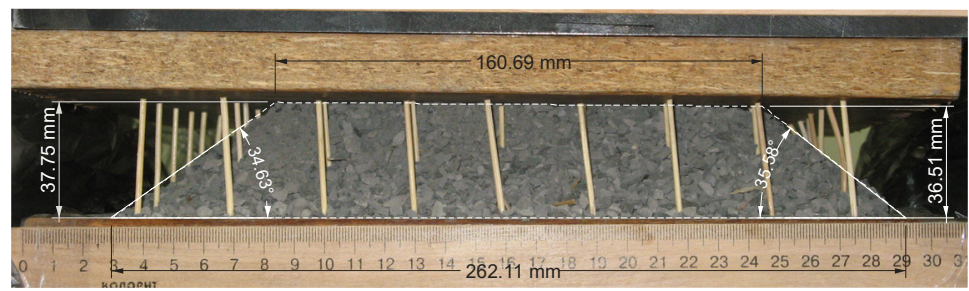

Fig. 6. Representation of a rock pack model.

$a$

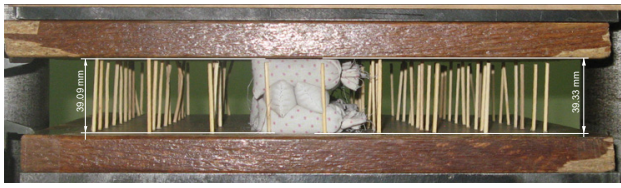

$b$

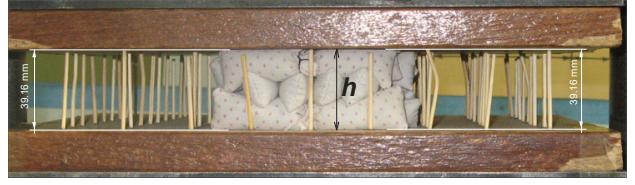

Fig. 7. Representation of rock wall models $1.1 h$ (a) and $2.2 h$ (b) wide.
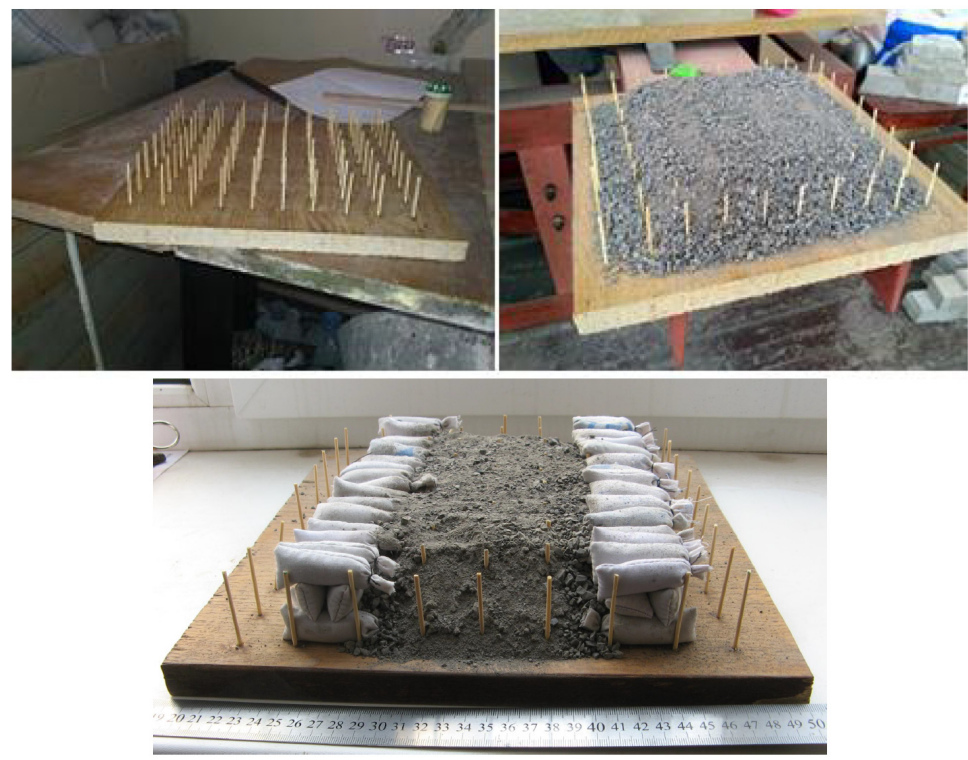

Fig. 8. Representation of the models before and after testing.

After the models were prepared, their testing was carried out. For this purpose, by means of the hydraulic press $\Pi-50$, the models were squeezed in turns and their linear parameters were fixed with the electronic caliper gauge INTERTOOL MT-3006. Photographic evidence was also taken with Canon PowerShot A710 digital camera. Press load was measured by means of the integrated universal measuring system SI-9v2 "Universal" displaying values of the current load and its application speed. Several photographs of the modeling stages are shown in Figure 9.

While the models were tested, there were some changes in the linear parameters of the structures. In particular, all of them, depending on the load, decreased in height; in models without walls, the rock pack partially extended and its width increased; in wall models the bags were compacted and there were some holed bags. 

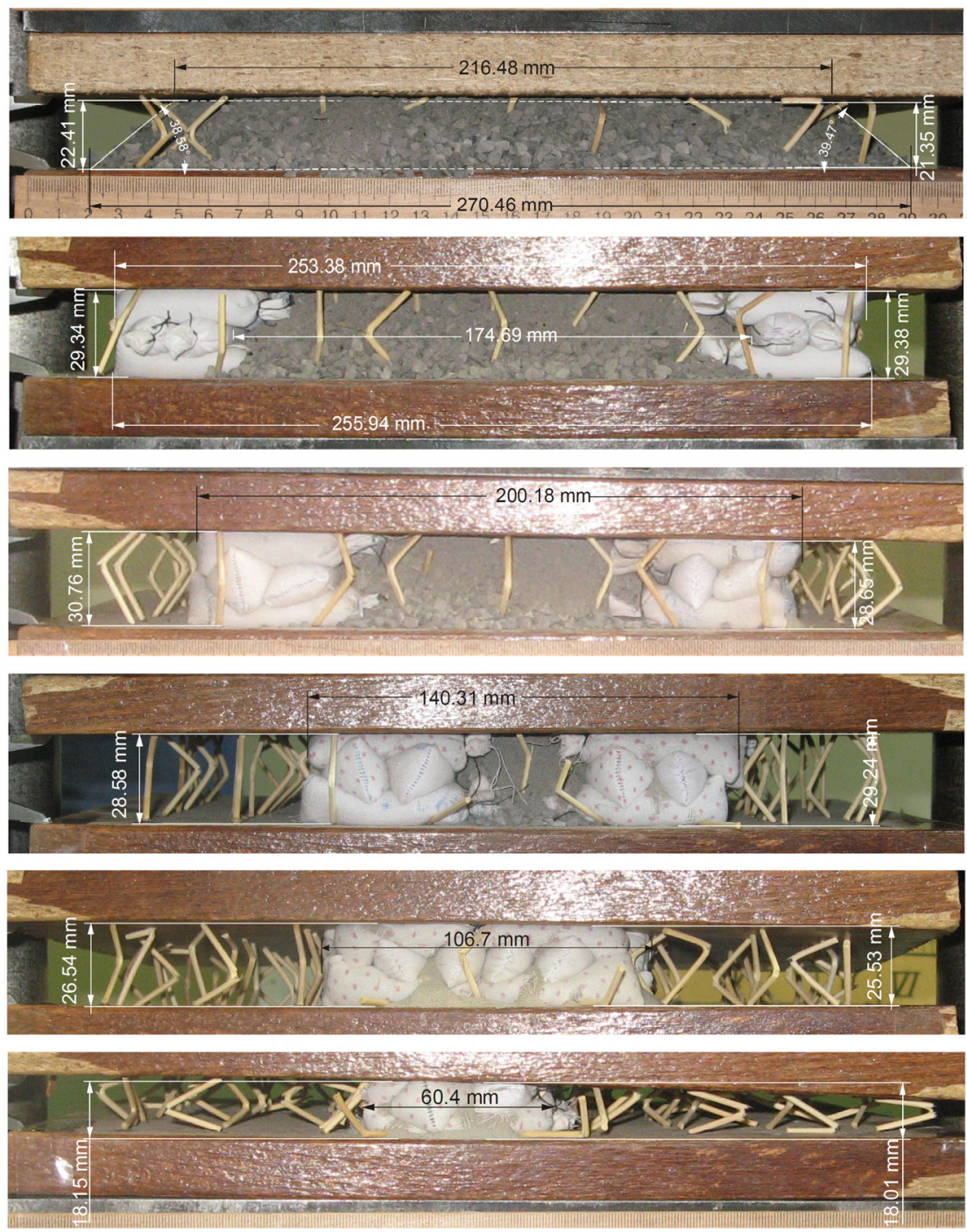

Fig. 9. Representation of the final modeling stage.

The limit load value was calculated by the formula [26]:

$$
g_{m}=g_{f} \frac{\gamma_{m}}{\gamma_{f}} \frac{l_{m}}{l_{f}},
$$

where $g_{f}$ is rock pressure value in field; $\left(\gamma_{m} / \gamma_{f}\right)$ is the ratio of bulk weight of field materials and the model; $\left(l_{m} / l_{f}\right)$ is the geometric simulation scale, i.e. at $\gamma_{m} / \gamma_{f}=1$ and $l_{m} / l_{f}=0.04-$ $g_{m}=0.04 g_{f}$. Thus, at depth of $1000 \mathrm{~m}$, assuming that the working contour stress can exceed 2 times the stress in virgin ground [22], the $g_{m}$ should be $2 \mathrm{MPa}$, and taking into account the bearing surface area, the load intensity should be $180 \mathrm{kN}$. Therefore, the boundary load was $200 \mathrm{kN}$.

Having measured shrinkage of structures in models, we determined their relative yielding strength depending on the load intensity (Fig. 10). Generally, the models yielding 
at maximum load reached $52 \%$, depending on the particular design, and this value corresponded to the rock wall $1.1 \mathrm{~h}$ wide. Widening the rock wall twofold to $2.2 \mathrm{~h}$ ensured the yielding of $36 \%$, which was almost equal to the rock pack yielding (38\%). It was concluded that the use of rock legs only is not effective enough.

Testing of integrated structures made of rock pack and bag walls showed that in models of different width the value of yielding was almost the same and at maximum load it was $26 \%$, which is almost $40 \%$ less than when protected by rock pack and a rock wall $2.2 \mathrm{~h}$ wide. That is, it wasn't reasonable to increase the rock pack width by more than $1.3 h$. Thus, for the simulated conditions, the width of the integrated construction was $3.5 h$, including the rock pack $1.3 \mathrm{~h}$ wide, which corresponds to the analytical results of the study and confirms the correctness of the previously obtained dependence of the rock pack width in the integrated structure on impact factors. But the equation (3) presupposes the condition of preserving the equilibrium state of running ground in the rock pack, that is, at the estimated width of $1.3 \mathrm{~h}$ there should not have been any roof subsidence, and, in our case, it is equivalent to $0.26 h$. This is explained by the fact that at the first stage of the loading in the rock pack there is no bearing core and the structure intensively changes its shape. At the second stage, when the construction yielding is exhausted, it works when there is the core in the rock pack. The justification of the mechanism for forming the core in the construction requires further research. In general, the obtained results allowed us to clarify the parameters of the integrated protective structure and confirmed the adequacy of the analytical dependence of the rock pack width in this structure on the impact factors.

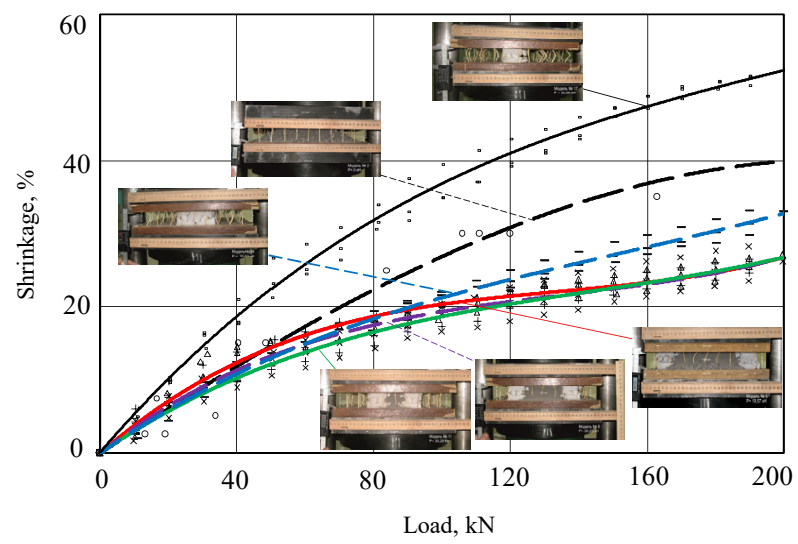

Fig. 10. Graphs showing dependence of protective structures shrinkage amount on load intensity under various construction parameters.

\section{Conclusions}

The conducted research made it possible to draw the following conclusions:

- the correlation of the rock wall reaction to its total load value is established;

- the condition for ensuring the stability of the integrated protective structure is substantiated;

- the dependence of the amount of protective structures shrinkage on the load intensity under various parameters of structures (rock pack, rock walls and integrated structures) is determined;

- it was established that there is yielding value of $26 \%$ in the integrated protective structure made of rock walls and rock pack between them;

- the analytical dependence of the rock pack width in the integrated protective structure 
on impact factors is specified, by means of which it is possible to determine the minimum required rock pack width for effective maintenance of top rock;

- it is established that exceeding the minimum required rock pack width in the integrated structure is not appropriate.

The authors are grateful to the staff of the Department of Geotechnologies and Labor Protection of the Industrial Institute of Donetsk National Technical University for the assistance in conducting laboratory research.

\section{References}

1. Bulat, A.F., Popovych, I.M., Vivcharenko, O.V., \& Krukovskyi, O.P. (2014). Tekhnolohiia ankernoho kriplennia hirnychykh vyrobok na shakhtakh Ukrainy: stan i perspektyvy. Uhol Ukrainy, (2), 3-7.

2. Stanisław Prusek, Sylwester Rajwa, Aleksander Wrana, \& Alicja Krzemień. (2017). Assessment of roof fall risk in longwall coal mines. International Journal of Mining, Reclamation and Environment, 31(8), 558-574. http://doi.org/10.1080/17480930.2016.1200897

3. Gregory M. Molinda, Christopher Mark, \& D. Debasis. (2001). Using the coal mine roof rating (CMRR) to assess roof stability in U.S. coal mines. J Mines Met Fuels (India), 314-321. https://www.cdc.gov/niosh/mining/works/coversheet894.html

4. Pivniak, H.H., Tabachenko, M.M., Dychkovskyi, R.O., \& Falshtynskyi, V.S. (2015). Keruvannia ryzykamy v hirnychodobuvnii diialnosti. Dnipropetrovsk: Natsionalnyi hirnychyi universytet.

5. Małkowski Piotr, Ostrowski Łukasz, \& Bachanek Piotr. (2017). Modelling the Small Throw Fault Effect on the Stability of a Mining Roadway and Its Verification by In Situ Investigation. Energies, 10(12), 2082. http://doi.org/10.3390/en10122082

6. Piotr Małkowski, Łukasz Ostrowski, \& Piotr Bachanek. (2017). The impact of the low throw fault on the stability of roadways in a hard coal mine. Studia Geotechnica et Mechanica, 39(1), 63-72. http://doi.org/10.1515/sgem-2017-0006

7. Qiangling Yao, Xuehua Li, Fan Pan, Teng Wang, \& Guang Wang. (2016). Deformation and Failure Mechanism of Roadway Sensitive to Stress Disturbance and Its Zonal Support Technology. Shock and Vibration, (6), 1-14. http://doi.org/10.1155/2016/1812768

8. Weijian Yu, Weijun Wang, Xinyuan Chen, \& Shaohua Du. (2015). Field investigations of high stress soft surrounding rocks and deformation control. Journal of Rock Mechanics and Geotechnical Engineering, (7), 421-433.

9. Frith, R., Reed, G., \& McKinnon, M. (2017). Fundamental principles of an effective reinforcing roof bolting strategy in horizontally layered roof strata and three areas of potential improvement. In 17th Coal Operators' Conference (pp. 149-170). Australia: University of Wollongong.

10. Hapieiev, S.M., Khoziaikina, N.V., Tereshchuk, R.M., \& Kovalenko, V.V. (2016). Resursozberihaiuchi tekhnolohii upravlinnia stiikistiu protiazhnykh vyrobok vuhilnykh shakht. Dnipro: Natsionalnyi hirnychyi universytet.

11. Minghe Ju, , Xuehua Li, Qiangling Yao, Shengyou Liu, Shun Liang, \& Xiaolin Wang. (2017). Effect of sand grain size on simulated mining-induced overburden failure in physical model tests. Engineering Geology, 1-14. http://doi.org/10.1016/j.enggeo.2017.05.015

12. Nehrii, S., \& Nehrii, T. (2017). Conditions of use trapezoidal security installations. Journal of Donetsk Mining Institute, 2(41), 7-18 http://doi.org/10.31474/1999-981x-2017-2-7-18

13. Rui Gao, Bin Yu, Hongchun Xia, \& Hongfei Duan. (2017). Reduction of Stress Acting on a Thick, Deep Coal Seam by Protective-Seam Mining. Energies, 10(8), 1209. http://doi.org/10.3390/en10081209

14. Nan Zhou, Jixiong Zhang, Hao Yan \& Meng Li. (2017). Deformation Behavior of Hard Roofs in Solid Backfill Coal Mining Using Physical Models. Energies, 10(4), 557. http://doi.org/10.3390/en10040557 
15. Demin, V.F., Fofanov, O.B., Demina, T.V., \& Yavorskiy, V.V. (2017). Anchoring of development workings in a zone of influence of mining in case of the level anchoring system. IOP

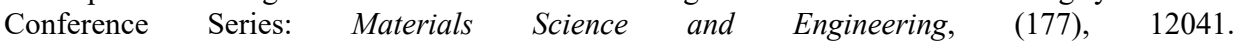
http://doi.org/10.1088/1757-899X/177/1/012041

16. Solodiankin, A.V., Mashurka, S.V., Dudka, I.V., \& Kuziaeva, O.A. (2015). Provision stability local workings for reusing under the state enterprise "Coal company "Yuzhnodonbasskaya №1". Up-to-date resource- and energy- saving technologies in mining industry, 1(15), 96-105.

17. Khalimendik, Yu.M., Bruy, A.V., \& Baryshnikov, A.S. (2013). Issledovanie deformirovaniya porod krovli vyemochnykh vyrabotok. Transactions of UkrNDMI NAN Ukraine, 13(1), 21-30.

18. Bondarenko, V., Gryadushchiy Yu., Kovalevskaya, I., \& Simanovich, G. (2009). Metodika issledovaniya vliyaniya poperechnogo secheniya plastovoy vyrabotki vida krepi na peremescheniya eye kontura. School of Underground Mining 2009, 23-29.

19. Kozhushok, O., \& Ilyashov, M. (2009). Matematicheskoe modelirovanie raboty kombinirovannoy okhrannoy sistemy pri podderzhanii vyemochnogo shtreka za lavoy. School of Underground Mining 2009, 185-193.

20. Solodiankin, O.V., Dudka, I., Tereshchuk, R., \& Hryhoriev, O. (2017). Okhorona pidhotovchykh vyrobok, shcho vykorystovuiut povtorno, $v$ umovakh antratsytovykh shakht. Dnipro: Natsionalnyi hirnychyi universytet.

21. Nehrii, S. (2016). Tests of rock bands with limited suppleness. Journal of Donetsk Mining Institute, 2(39), 54-60.

22. Nehrii, S., \& Nehrii, T. (2017). Determination of parameters of rock bands with limited suppleness. Transactions of Kremenchuk Mykhailo Ostrohradskyi National University, 1/2017 (102), 50-57.

23. SOU 10.1.00185790.011:2007.(2007). Pidhotovchi vyrobky na polohykh plastakh. Vybir kriplennia, sposobiv i zasobiv okhorony. Kyiv: Donetskyi vuhilnyi instytut.

24. Khazipov, I.V. (2009). Razrabotka sposobov sozdaniya iskusstvennykh porodnykh sooruzheniy dlya okhrany povtorno ispol'zuemykh vyrabotok. Rh.D. DonNTU.

25. Yanko, S.V., Kasian M., Petrenko, Yu, \& etc. (2003). Suchasni problemy provedennia ta pidtrymannia hirnychykh vyrobok hlybokykh shakht. Donetsk: DUNVHO.

26. Borisov, A.A. (1964). Raschety gornogo davleniya v lavakh pologikh plastov. Moskva: Nedra. 